\title{
The Effect of High-Calorie Meal Consumption on Oxidative Stress and Endothelial Dysfunction in Healthy Male Adults
}

\author{
S. KACKOV ${ }^{1}$, A.-M. SIMUNDIC ${ }^{2}$, N. NIKOLAC ${ }^{2}$, I. CELAP ${ }^{2}$, L. DUKIC ${ }^{2}$, D. RUZIC ${ }^{2}$, \\ M. BILUSIC ${ }^{1}$ \\ ${ }^{1}$ Medical Biochemistry Laboratory, Policlinic Bonifarm, Zagreb, Croatia, ${ }^{2}$ University Department \\ of Chemistry, Sisters of Mercy University Hospital Center, Zagreb, Croatia
}

Received December 10, 2012

Accepted May 2, 2013

On-line July 17, 2013

\section{Summary}

Several authors have reported the association of postprandial hypertriglyceridemia with oxidative stress, systemic inflammation and endothelial dysfunction. Our aim was to investigate the effect of high-calorie meal on blood markers of oxidative stress and endothelial dysfunction and the association of APOA5 $-1131 \mathrm{~T} / \mathrm{C}$ and $-250 \mathrm{G} / \mathrm{A}$ hepatic lipase (HL) polymorphisms with postprandial triglyceride response. This study included 102 healthy male volunteers. All participants consumed a highcalorie meal (823 calories, $50 \mathrm{~g}$ fat, $28 \mathrm{~g}$ protein, $60 \mathrm{~g}$ carbohydrates). Total cholesterol, triglycerides, HDL-cholesterol, LDL-cholesterol, hsCRP, TAS and ICAM-1 were measured at fasting state and postprandially. APOA5 -1131T/C and -250G/A $\mathrm{HL}$ polymorphisms were also determined. Postprandial triglycerides were significantly increased (1.4 (1.1-2.1) vs. 2.4 (1.9-3.3) $\mathrm{mmol} / \mathrm{l}, \mathrm{P}<0.001)$. Average triglyceride increase was $1.0 \pm 0.7 \mathrm{mmol} / \mathrm{l}$ (65\%). Concentration of triglycerides, HDLcholesterol, LDL-cholesterol, TAS and ICAM-1 differed significantly between the fasting state and postprandial measurements $(P<0.001)$. However, those differences were within the limits of analytical imprecision. Other parameters did not change $3 \mathrm{~h}$ after the meal. Triglycerides response did not differ respective to the APOA5 and $\mathrm{HL}$ polymorphisms. Family history of hypertension and acute myocardial infarction were associated with higher postprandial triglyceride concentrations. Postprandial hypertriglyceridemia is not associated with increased concentrations of hSCRP, TAS and ICAM-1. Furthermore, APOA5 $-1131 \mathrm{~T} / \mathrm{C}$ and $-250 \mathrm{G} / \mathrm{A}$ HL polymorphisms are not associated with different postprandial triglyceride response.

\section{Key words}

Apolipoprotein A5 - Hepatic lipase • Postprandial hypertriglyceridemia $\bullet$ Oxidative stress $\bullet$ Endothelial dysfunction

\section{Corresponding author}

Sanja Kackov, Medical biochemistry laboratory, Policlinic Bonifarm, Laginjina 16, 10000 Zagreb, Croatia. Fax: +3851 4604156. E-mail: sanjakackov@hotmail.com

\section{Introduction}

The increase in triglycerides of intestinal or hepatic origin during the day is defined as the postprandial hypertriglyceridemia. It has been postulated that postprandial increase of triglycerides leads to increased oxidative stress. Namely, triglycerides can participate directly in atherogenesis, particularly when exposed to oxygen free radicals or when associated with the formation of small, dense LDL particles (Karpe 1999, Chapman et al. 2011).

Moreover, several authors have shown that postprandial hypertriglyceridemia might be associated with endothelial dysfunction and increased risk for coronary artery disease (CAD) development. Endothelial dysfunction predicts risk of repeated cardiovascular incidents (Nappo et al. 2002, Fernández-Real et al. 2010).

However, results from different studies are still conflicting and the effect of high fat meal on the endothelial homeostasis is not yet clear. Conflicting literature results exist mostly due to the large differences in study design. 
Among the genetic factors associated with variability of serum triglyceride concentrations in humans, the apolipoprotein A5 gene (APOA5) plays an important role in plasma triglyceride homeostasis (Pennacchio and Rubin 2003). Another important determinant of lipid level is hepatic lipase (HL). The activity of hepatic lipase positively correlates with LDLcholesterol and inversely correlates with HDL-cholesterol (Santamarina-Fojo et al. 2004).

Several investigators have reported that the polymorphism -1131T/C in APOA5 gene (Moreno-Luna et al. 2007, Maasz et al. 2008) and the polymorphism 250G/A in hepatic lipase gene (Jiménez-Gómez et al. 2008, Valdivielso et al. 2008) could be responsible for differences in postprandial response in humans. However, these associations are not yet fully understood.

We hypothesized that postprandial hypertriglyceridemia leads to the oxidative stress and endothelial dysfunction. Moreover, our hypothesis was that different response of hypertriglyceridemia is genetically determined by APOA5 and HL genetic polymorphisms.

This study aimed to investigate the effect of high-calorie meal on oxidative stress and endothelial dysfunction; and the association of APOA5 -1131T/C and $-250 \mathrm{G} / \mathrm{A}$ HL polymorphisms with different response to the standardized high-calorie meal in the group of healthy male adults.

\section{Materials and Methods}

\section{Subjects}

This study was performed in Policlinic Bonifarm and Sisters of Mercy University Hospital Center, during November 2009 to October 2010. We have prospectively included 102 healthy male Croatian volunteers, referred by a general practitioner, for a periodic medical check-up. Inclusion criteria were: age from 50 to 70 years, the absence of acute illness.

Exclusion criteria were: diabetes mellitus, recent surgery ( $<2$ months) or weight gain or loss, personal history of acute myocardial infarction or stroke and the use of oral hypoglycemic or hypolipidemic agents.

Height, weight, waste and hip circumference were measured by a trained nurse, for all participants.

Written informed consent was obtained from all participants.

The study was approved by the Ethics Committee of the Sisters of Mercy University Hospital
Center, Zagreb, Croatia.

\section{Study protocol}

All participants have consumed standardized high-calorie meal (823 kcal) composed of $120 \mathrm{~g}$ French bread (318 kcal), $75 \mathrm{~g}$ salami (23\% fat, $213 \mathrm{kcal}), 50 \mathrm{~g}$ cheese (45\% fat, $185 \mathrm{kcal})$ and $15 \mathrm{~g}$ margarine (107 kcal) (Liu et al. 2008). During the next $3 \mathrm{~h}$, the participants did not eat and did not consume any drugs. They were only allowed to drink water and it was possible to walk.

For each study subject, two samples were drawn: one after the overnight fast (in the morning between 7 and 9 o'clock) and another $3 \mathrm{~h}$ after the high-calorie meal.

For all patients total cholesterol, triglycerides, HDL-cholesterol, LDL-cholesterol, high-sensitivity Creactive protein (hsCRP), total antioxidant status (TAS) and intercellular adhesion molecule-1 (ICAM-1) were measured at fasting state and postprandially and APOA5 $-1131 \mathrm{~T} / \mathrm{C}$ and -250G/A HL genetic polymorphisms were determined.

\section{Samples}

The blood collected in Becton Dickinson Vacutainer ${ }^{\circledR}$ K3-EDTA tubes (Franklin Lakes, NJ, USA) was used for determination genetic polymorphisms, while serum samples collected using Becton Dickinson Vacutainer ${ }^{\circledR}$ tubes (Franklin Lakes, NJ, USA) were used for measuring biochemical parameters. Sera were centrifuged for $10 \mathrm{~min}$ at a centrifugation force of $3500 \mathrm{~g}$ on a benchtop centrifuge.

Biochemical parameters were analyzed within $24 \mathrm{~h}$, while sera for TAS and ICAM-1 measurements were stored at $-20{ }^{\circ} \mathrm{C}$ until analysis.

\section{Anthropometric measurements and family history}

Weight was measured, while subjects were minimally clothed without shoes, on a calibrated scale to the nearest $0.1 \mathrm{~kg}$. Height was measured in a standing position, without shoes, with a digital stadiometer to the nearest $0.1 \mathrm{~cm}$. Body mass index (BMI) was calculated as weight in kilograms divided by the square of height in meters $\left(\mathrm{kg} / \mathrm{m}^{2}\right)$.

The measurement of waist circumference was done at the approximate midpoint between the lower margin of the last palpable rib and the top of the iliac crest. The measurement hip circumference was done around the widest portion of the buttocks (WHO Expert Consultation 2008). Waist to hip ratio (w/h) was 
calculated as the waist circumference divided by the hip circumference.

Smoking status and family history for cardiovascular diseases (hypertension, diabetes mellitus, acute myocardial infarction, stroke) was assessed for each individual. Current smokers were individuals who smoked one or more cigarettes per day, whereas exsmokers and those who have never smoked have been considered as non-smokers.

\section{Methods}

Concentrations of total cholesterol, triglycerides and HDL-cholesterol were measured by standard enzymatic methods and hsCRP were determined by immunoturbidimetry on analyzer Roche Diagnostics Cobas Integra 400 plus (Mannheim, Germany).

LDL-cholesterol was measured by direct method on analyzer Roche Diagnostics Cobas Integra 400 plus (Mannheim, Germany).

TAS was determined by colorimetric method using a commercially available RANDOX kit and Randox TAS Control (Crumlin, County Antrim, United Kingdom) with Beckman Coulter Olympus AU 640 biochemistry analyzer (Brea, CA, SAD). Method linearity was $0-2.5 \mathrm{mmol} / \mathrm{l}$, as declared by the manufacturer. Maximum intra-assay precision (CV) was $3.25 \%$ at the mean TAS $1.06 \mathrm{mmol} / \mathrm{l}$ and maximum inter-assay was $3.03 \%$ at the mean TAS $0.97 \mathrm{mmol} / \mathrm{l}$.

ICAM-1 was measured by Bender MedSystems enzymimmunoassay (ELISA) using Human sICAM-1 Platinum ELISA kit (Vienna, Austria) with ELISA Humareader 2106 (Wiesbaden, Germany). The limit of detection of human ICAM-1 was $2.2 \mathrm{ng} / \mathrm{ml}$ and overall intra-assay coefficient of variation was $4.1 \%$.

High Pure Roche PCR Template Preparation Kit (Mannheim, Germany) was used for isolation of genomic DNA.

The $-1131 \mathrm{~T} / \mathrm{C}$ polymorphism was determined by restriction fragment length polymorphism (RFLP) after polymerase chain reaction (PCR) amplification (PCRRFLP) method described by Maasz et al. (2008).

In brief, two primers (Invitrogen Corporation, Carlsbad, CA, USA) for $-1131 \mathrm{~T} / \mathrm{C}$ with the following sequences were used: the forward primer 5'-CCC CAG GAA CTG GAG CGA AAT T-3' and the reverse primer 5'-TTC AAG CAG AGG GAA GCC TGTA-3'.

The PCR conditions for the detection of $-1311 \mathrm{~T} / \mathrm{C}$ : initial denaturation of $5 \mathrm{~min}$ at $97^{\circ} \mathrm{C}$ followed by 35 cycles of $60 \mathrm{~s}$ at $95^{\circ} \mathrm{C} ; 45 \mathrm{~s}$ at $60{ }^{\circ} \mathrm{C} ; 60 \mathrm{~s}$ at $72^{\circ} \mathrm{C}$ and a final extension of $10 \mathrm{~min}$ at $72{ }^{\circ} \mathrm{C}$.

The PCR amplification in the region of $-1131 \mathrm{~T} / \mathrm{C}$ resulted in a 398-bp product, which was digested with $\mathrm{Mse}$ I restriction enzyme over the night at $37^{\circ} \mathrm{C}$ and electrophoresed through an ethidium-bromidestained $4 \%$ agarose gel.

In the samples with a TT genotype the digestion resulted in 22-, 109- and 267-bp bands. In the samples carrying the mutation in heterozygous form (TC), 22-, 109-, 267- and 289-bp digestion products were detected. In the samples with a CC genotype, 109- and 289-bp products were formed.

The $-250 \mathrm{G} / \mathrm{A}$ polymorphism was genotyped by real time PCR (RT-PCR) and melting curve analysis using Roche Diagnostics LightCycler System 1.5 (Mannheim, Germany) according to manufacturer's instructions.

Two primers LightSNiP rs2070895 LIPC (TIB MOLBIOL, Berlin, Germany) for $-250 \mathrm{G} / \mathrm{A}$ with the following sequences were used: the forward primer 5'CCT ACC CCG ACC TTT GGC AG-3' and the reverse primer 5'-GGG GTC CAG GCT TTC TTG G-3'.

\section{Statistical analysis}

Qualitative data were presented as counts and percentages. Relative differences in frequencies between groups were assessed by Chi-square test.

Quantitative variables were assessed for normality using the Kolmogorov-Smirnov test. The variables with normal distribution were described by arithmetic mean $(\overline{\mathrm{x}})$ and standard deviation $( \pm \mathrm{SD})$, and those not distributed normally were presented by median (M) and interquartile range (IQR). In addition, the age was expressed as median and range (minimummaximum).

Paired Student's t-test and Wilcoxon Rank Sum test were used for comparison of dependent variables (for normal and asymmetric distributions, respectively). Student's t-test and Mann-Whitney Rank Sum test were used to test for differences between independent variables which were not normally distributed (for normal and asymmetric distributions, respectively). The Spearman's rank coefficient of correlation was used for testing correlation between biochemical parameters (Simundic 2012).

Statistical analysis was performed by using MedCalc 12.1.4.0 statistical software (MedCalc Software, Mariakerke, Belgium). $\mathrm{P}<0.05$ was set as the level of significance. 


\section{Results}

The baseline demographic and biochemistry characteristics of the subjects included in this study $(\mathrm{N}=102)$ are presented in Table 1. Our study subjects were predominantly obese with an average $\mathrm{BMI} \geq 25 \mathrm{~kg} / \mathrm{m}^{2}$.

Table 1. Clinical and biochemical characteristics of study subjects.

\begin{tabular}{ll}
\hline Variables & $\mathrm{N}=102$ \\
\hline Age (years) & $58(52-68)$ \\
BMI $\left(\mathrm{kg} / \mathrm{m}^{2}\right)$ & $28.3 \pm 3.8$ \\
Waist circumference (cm) & $105 \pm 9$ \\
Hip circumference (cm) & $109 \pm 7$ \\
wh & $0.96 \pm 0.05$ \\
Smokers (N, \%) & $35(34)$ \\
\hline
\end{tabular}

Family history for cardiovascular diseases

\begin{tabular}{ll} 
Hypertension (N, \%) & $54(53)$ \\
Diabetes mellitus (N, \%) & $13(13)$ \\
Acute myocardial infarction (N, \%) & $24(24)$ \\
Stroke (N, \%) & $16(16)$ \\
\hline
\end{tabular}

The variables were described by arithmetic mean \pm standard deviation or with median and interquartile range or as counts and percentages. The age was expressed as median and range (minimum-maximum).

Table 2 shows concentrations of fasting and postprandial concentration of biochemical parameters, markers of inflammation, oxidative stress and endothelial dysfunction. In our study group, triglycerides have showed a statistically significant postprandial increase (1.4 (1.1-2.1) vs. 2.4 (1.9-3.3) mmol/l, $\mathrm{P}<0.001)$. The average postprandial increase of triglyceride concentration was $1.0 \pm 0.7 \mathrm{mmol} / 1(65 \%)$.

Concentration of triglycerides, HDL-cholesterol, LDL-cholesterol, TAS and ICAM-1 differed significantly between the fasting state and postprandial measurements $(\mathrm{P}<0.001)$. However, those differences were within the limits of analytical imprecision. Differences in total cholesterol $(\mathrm{P}=0.087)$ and hsCRP $(\mathrm{P}=0.080)$ were not statistically significant (Table 2).

\section{Genetic determinants of postprandial response}

The APOA5 -1131T/C genotype distribution among the 102 study subjects was as follows: 88 homozygotes wild type (T/T), 9 heterozygotes $(\mathrm{T} / \mathrm{C})$ and 3 homozygotes polymorphic allele $(\mathrm{C} / \mathrm{C})$. Due to the small number of $\mathrm{C} / \mathrm{C}$ homozygotes, we combined $\mathrm{T} / \mathrm{C}$ and $\mathrm{C} / \mathrm{C}$ into one group.

Table 2. Concentrations of biochemical parameters, markers of inflammation, oxidative stress and endothelial dysfunction, fasting and postprandial in study group ( $\mathrm{N}=102)$.

\begin{tabular}{|c|c|c|c|}
\hline Variables & $\begin{array}{l}\text { Fasting } \\
\mathrm{N}=102\end{array}$ & $\begin{array}{l}\text { Postprandial } \\
\mathrm{N}=102\end{array}$ & $\mathbf{P}$ \\
\hline $\begin{array}{l}\text { Triglycerides } \\
(\mathrm{mmol} / \mathrm{l})\end{array}$ & $\begin{array}{l}1.4 \\
(1.1-2.1)\end{array}$ & $\begin{array}{l}2.4 \\
(1.9-3.3)\end{array}$ & $<0.001$ \\
\hline $\begin{array}{l}\text { Total cholesterol } \\
\text { (mmol/l) }\end{array}$ & $6.0 \pm 1.1$ & $5.9 \pm 1.1$ & 0.087 \\
\hline $\begin{array}{l}\text { HDL-cholesterol } \\
\text { (mmol/l) }\end{array}$ & $\begin{array}{l}1.3 \\
(1.1-1.5)\end{array}$ & $\begin{array}{l}1.2 \\
(1.1-1.4)\end{array}$ & $<0.001$ \\
\hline $\begin{array}{l}\text { LDL-cholesterol } \\
(\mathrm{mmol} / \mathrm{l})\end{array}$ & $4.0 \pm 1.0$ & $3.8 \pm 1.0$ & $<0.001$ \\
\hline $\begin{array}{l}\text { hsCRP } \\
(m g / l)\end{array}$ & $\begin{array}{l}1.72 \\
(0.88-3.04)\end{array}$ & $\begin{array}{l}1.64 \\
(0.90-3.03)\end{array}$ & 0.080 \\
\hline $\begin{array}{l}\text { TAS } \\
(\mathrm{mmol} / \mathrm{l})\end{array}$ & $1.82 \pm 0.02$ & $1.83 \pm 0.03$ & $<0.001$ \\
\hline $\begin{array}{l}I C A M-1 \\
(\mathrm{ng} / \mathrm{ml})\end{array}$ & $301 \pm 84$ & $269 \pm 84$ & $<0.001$ \\
\hline
\end{tabular}

The variables were described by arithmetic mean \pm standard deviation or with median and interquartile range.

Table 3 shows concentrations of biochemical parameters, markers of inflammation, oxidative stress and endothelial dysfunction, fasting and postprandial in APOA5 subgroups.

In both APOA5 genotype subgroups (group 1 and group $(2+3))$ there was a significant increase in the postprandial concentrations of triglycerides $(\mathrm{P}<0.001)$. However, the mean relative triglyceride increase did not differ between APOA5 subgroups $( \pm \mathrm{SD})(0.9 \pm 0.7 \mathrm{mmol} / 1$ (65\%) vs. $1.3 \pm 0.8 \mathrm{mmol} / 1(60 \%) ; \mathrm{P}=0.099$, in APOA5 group 1 and APOA5 group (2+3), respectively). Most of the measured parameters differed before and after the meal in both genotype subgroups, but differences were not clinically meaningful and were not considered significant.

The HL -250G/A genotype distribution among the 102 examined subjects was as follows: 71 homozygotes wild type (G/G), 26 heterozygotes (G/A) and 4 homozygotes polymorphic allele (A/A). Again, due to the small number of $\mathrm{A} / \mathrm{A}$ homozygotes, we combined $\mathrm{G} / \mathrm{A}$ and $\mathrm{A} / \mathrm{A}$ into one group. 
Table 3. Concentrations of biochemical parameters, markers of inflammation, oxidative stress and endothelial dysfunction, fasting and postprandial in study subgroups for the $-1131 \mathrm{~T} / \mathrm{C}$ polymorphism in APOA5 gene.

\begin{tabular}{|c|c|c|c|c|c|c|c|c|}
\hline \multirow[t]{2}{*}{ Variables } & \multicolumn{3}{|c|}{$\begin{array}{l}\text { APOA5 Group } 1 \\
(\mathrm{~T} / \mathrm{T}) \\
\mathrm{N}=\mathbf{8 8}\end{array}$} & \multicolumn{3}{|c|}{$\begin{array}{l}\text { APOA5 Group }(2+3) \\
(\mathrm{T} / \mathrm{C}+\mathrm{C} / \mathrm{C}) \\
\mathrm{N}=12\end{array}$} & \multicolumn{2}{|c|}{$\begin{array}{l}\text { P } \\
\text { Group } 1 \text { vs. Group } \\
(2+3)\end{array}$} \\
\hline & Fasting & Postprandial & $\mathbf{P}$ & Fasting & Postprandial & $\mathbf{P}$ & Fasting & Postprandial \\
\hline $\begin{array}{l}\text { Triglycerides } \\
\text { (mmol/l) }\end{array}$ & $\begin{array}{l}1.4 \\
(1.1-2.0)\end{array}$ & $\begin{array}{l}2.4 \\
(1.8-3.1)\end{array}$ & $<0.001$ & $\begin{array}{l}1.8 \\
(1.3-3.3)\end{array}$ & $\begin{array}{l}3.4 \\
(2.1-4.7)\end{array}$ & $<0.001$ & 0.074 & 0.061 \\
\hline $\begin{array}{l}\text { Total } \\
\text { cholesterol } \\
\text { (mmol/l) }\end{array}$ & $\begin{array}{l}5.9 \\
(5.0-6.6)\end{array}$ & $\begin{array}{l}5.9 \\
(5.1-6.6)\end{array}$ & 0.037 & $\begin{array}{l}6.2 \\
(5.3-6.8)\end{array}$ & $\begin{array}{l}6.0 \\
(5.2-6.6)\end{array}$ & 0.175 & 0.614 & 0.840 \\
\hline $\begin{array}{l}\text { HDL- } \\
\text { cholesterol } \\
\text { (mmol/l) }\end{array}$ & $\begin{array}{l}1.3 \\
(1.1-1.5)\end{array}$ & $\begin{array}{l}1.2 \\
(1.1-1.4)\end{array}$ & $<0.001$ & $\begin{array}{l}1.2 \\
(1.1-1.3)\end{array}$ & $\begin{array}{l}1.1 \\
(1.0-1.3)\end{array}$ & 0.016 & 0.318 & 0.230 \\
\hline $\begin{array}{l}\text { LDL- } \\
\text { cholesterol } \\
\text { ( } \mathrm{mmol} / \mathrm{l})\end{array}$ & $\begin{array}{l}4.0 \\
(3.1-4.7)\end{array}$ & $\begin{array}{l}3.9 \\
(3.0-4.5)\end{array}$ & $<0.001$ & $\begin{array}{l}3.9 \\
(3.0-4.7)\end{array}$ & $\begin{array}{l}3.7 \\
(2.8-4.8)\end{array}$ & 0.077 & 0.779 & 0.945 \\
\hline $\begin{array}{l}h s C R P \\
(m g / l)\end{array}$ & $\begin{array}{l}1.80 \\
(0.88-3.12)\end{array}$ & $\begin{array}{l}1.73 \\
(0.90-3.27)\end{array}$ & 0.181 & $\begin{array}{l}1.16 \\
(0.94-2.32)\end{array}$ & $\begin{array}{l}1.26 \\
(0.92-2.11)\end{array}$ & 0.175 & 0.581 & 0.511 \\
\hline $\begin{array}{l}\text { TAS } \\
(\mathrm{mmol} / \mathrm{l})\end{array}$ & $\begin{array}{l}1.82 \\
(1.81-1.84)\end{array}$ & $\begin{array}{l}1.83 \\
(1.81-1.85)\end{array}$ & $<0.001$ & $\begin{array}{l}1.83 \\
(1.81-1.84)\end{array}$ & $\begin{array}{l}1.82 \\
(1.81-1.85)\end{array}$ & 0.164 & 0.992 & 0.505 \\
\hline $\begin{array}{l}I C A M-1 \\
(\mathrm{ng} / \mathrm{ml})\end{array}$ & $\begin{array}{l}287 \\
(245-349)\end{array}$ & $\begin{array}{l}252 \\
(212-307)\end{array}$ & $<0.001$ & $\begin{array}{l}286 \\
(236-349)\end{array}$ & $\begin{array}{l}281 \\
(189-304)\end{array}$ & 0.064 & 0.715 & 0.983 \\
\hline
\end{tabular}

The variables were described by median and interquartile range.

Table 4. Concentrations of biochemical parameters, markers of inflammation, oxidative stress and endothelial dysfunction, fasting and postprandial in study subgroups for the $-250 \mathrm{G} / \mathrm{A}$ polymorphism in hepatic lipase gene.

\begin{tabular}{|c|c|c|c|c|c|c|c|c|}
\hline \multirow[t]{2}{*}{ Variables } & \multicolumn{3}{|c|}{$\begin{array}{l}\text { HL Group } 1 \\
(\mathrm{G} / \mathrm{G}) \\
\mathrm{N}=71\end{array}$} & \multicolumn{3}{|c|}{$\begin{array}{l}\text { HL Group }(2+3) \\
(\mathbf{T} / \mathbf{A}+\mathbf{A} / \mathbf{A}) \\
\mathbf{N}=\mathbf{3 0}\end{array}$} & \multicolumn{2}{|c|}{$\begin{array}{l}\text { P } \\
\text { Group } 1 \text { vs. Group } \\
(2+3)\end{array}$} \\
\hline & Fasting & Postprandial & $\mathbf{P}$ & Fasting & Postprandial & $\mathbf{P}$ & Fasting & Postprandial \\
\hline $\begin{array}{l}\text { Triglycerides } \\
\text { (mmol/l) }\end{array}$ & $\begin{array}{l}1.5 \\
(1.1-2.4)\end{array}$ & $\begin{array}{l}2.5 \\
(1.9-3.6)\end{array}$ & $<0.001$ & $\begin{array}{l}1.3 \\
(1.1-1.7)\end{array}$ & $\begin{array}{l}2.1 \\
(1.7-2.8)\end{array}$ & $<0.001$ & 0.042 & 0.062 \\
\hline $\begin{array}{l}\text { Total } \\
\text { cholesterol } \\
\text { (mmol/l) }\end{array}$ & $\begin{array}{l}5.9 \\
(5.2-6.7)\end{array}$ & $\begin{array}{l}6.0 \\
(5.1-6.7)\end{array}$ & 0.102 & $\begin{array}{l}5.8 \\
(5.0-6.5)\end{array}$ & $\begin{array}{l}5.8 \\
(5.1-6.4)\end{array}$ & 0.031 & 0.397 & 0.240 \\
\hline $\begin{array}{l}\text { HDL- } \\
\text { cholesterol } \\
\text { (mmol/l) }\end{array}$ & $\begin{array}{l}1.3 \\
(1.1-1.5)\end{array}$ & $\begin{array}{l}1.2 \\
(1.1-1.5)\end{array}$ & $<0.001$ & $\begin{array}{l}1.3 \\
(1.2-1.5)\end{array}$ & $\begin{array}{l}1.2 \\
(1.1-1.4)\end{array}$ & $<0.001$ & 0.878 & 0.692 \\
\hline $\begin{array}{l}\text { LDL- } \\
\text { cholesterol } \\
\text { (mmol/l) }\end{array}$ & $\begin{array}{l}4.0 \\
(3.1-4.7)\end{array}$ & $\begin{array}{l}3.9 \\
(2.9-4.6)\end{array}$ & $<0.001$ & $\begin{array}{l}4.1 \\
(3.0-4.4)\end{array}$ & $\begin{array}{l}3.9 \\
(3.0-4.2)\end{array}$ & $<0.001$ & 0.513 & 0.496 \\
\hline $\begin{array}{l}h s C R P \\
(m g / l)\end{array}$ & $\begin{array}{l}1.79 \\
(0.89-2.86)\end{array}$ & $\begin{array}{l}1.71 \\
(0.90-2.84)\end{array}$ & 0.360 & $\begin{array}{l}1.42 \\
(0.87-3.15)\end{array}$ & $\begin{array}{l}1.30 \\
(0.92-3.21)\end{array}$ & 0.114 & 0.824 & 0.730 \\
\hline $\begin{array}{l}\text { TAS } \\
(\mathrm{mmol} / \mathrm{l})\end{array}$ & $\begin{array}{l}1.82 \\
(1.81-1.83)\end{array}$ & $\begin{array}{l}1.83 \\
(1.81-1.85)\end{array}$ & $<0.001$ & $\begin{array}{l}1.82 \\
(1.80-1.84)\end{array}$ & $\begin{array}{l}1.83 \\
(1.81-1.86)\end{array}$ & 0.016 & 0.433 & 0.785 \\
\hline $\begin{array}{l}I C A M-1 \\
(\mathrm{ng} / \mathrm{ml})\end{array}$ & $\begin{array}{l}285 \\
(245-347)\end{array}$ & $\begin{array}{l}249 \\
(217-299)\end{array}$ & $<0.001$ & $\begin{array}{l}294 \\
(240-349)\end{array}$ & $\begin{array}{l}275 \\
(194-339)\end{array}$ & 0.014 & 0.716 & 0.688 \\
\hline
\end{tabular}

The variables were described by median and interquartile range. 
Table 5. Concentrations of lipid parameter, markers of inflammation, oxidative stress and endothelial dysfunction, fasting and postprandial in study group $(\mathrm{N}=102)$ in relation to the BMI.

\begin{tabular}{|c|c|c|c|c|c|c|}
\hline Variables & $\begin{array}{l}\text { BMI }\left(<25 \mathrm{~kg} / \mathrm{m}^{2}\right) \\
\mathrm{N}=13\end{array}$ & $\begin{array}{l}\text { BMI }\left(\geq 25 \mathrm{~kg} / \mathrm{m}^{2}\right) \\
\mathrm{N}=89\end{array}$ & $\mathbf{P}$ & $\begin{array}{l}\text { BMI }\left(<30 \mathrm{~kg} / \mathrm{m}^{2}\right) \\
\mathrm{N}=74\end{array}$ & $\begin{array}{l}\text { BMI }\left(\geq 30 \mathrm{~kg} / \mathrm{m}^{2}\right) \\
\mathrm{N}=28\end{array}$ & $\mathbf{P}$ \\
\hline $\begin{array}{l}\text { Triglycerides, } \\
\text { fasting } \\
\text { (mmol/l) }\end{array}$ & $\begin{array}{l}1.2 \\
(1.0-1.4)\end{array}$ & $\begin{array}{l}1.5 \\
(1.1-2.3)\end{array}$ & 0.024 & $\begin{array}{l}1.4 \\
(1.0-2.0)\end{array}$ & $\begin{array}{l}1.6 \\
(1.2-2.3)\end{array}$ & 0.242 \\
\hline $\begin{array}{l}\text { Triglycerides, } \\
\text { postprandial } \\
\text { (mmol/l) }\end{array}$ & $\begin{array}{l}2.1 \\
(1.3-2.4)\end{array}$ & $\begin{array}{l}2.5 \\
(1.9-3.5)\end{array}$ & 0.025 & $\begin{array}{l}2.3 \\
(1.7-3.3)\end{array}$ & $\begin{array}{l}2.8 \\
(1.9-3.9)\end{array}$ & 0.301 \\
\hline $\begin{array}{l}\text { hsCRP, } \\
\text { fasting } \\
(m g / l)\end{array}$ & $\begin{array}{l}0.93 \\
(0.56-1.04)\end{array}$ & $\begin{array}{l}1.91 \\
(1.05-3.22)\end{array}$ & $<0.001$ & $\begin{array}{l}1.16 \\
(0.78-2.55)\end{array}$ & $\begin{array}{l}2.75 \\
(1.96-4.53)\end{array}$ & $<0.001$ \\
\hline $\begin{array}{l}\text { hsCRP, } \\
\text { postprandial } \\
(\mathrm{mg} / \mathrm{l})\end{array}$ & $\begin{array}{l}0.92 \\
(0.56-1.03)\end{array}$ & $\begin{array}{l}1.87 \\
(0.95-3.34)\end{array}$ & $<0.001$ & $\begin{array}{l}1.11 \\
(0.77-2.62)\end{array}$ & $\begin{array}{l}2.63 \\
(1.86-4.48)\end{array}$ & $<0.001$ \\
\hline $\begin{array}{l}T A S, \\
\text { fasting } \\
(\mathrm{mmol} / \mathrm{l})\end{array}$ & $1.81 \pm 0.02$ & $1.82 \pm 0.02$ & 0.054 & $1.82 \pm 0.02$ & $1.83 \pm 0.02$ & 0.207 \\
\hline $\begin{array}{l}T A S, \\
\text { postprandial } \\
(\mathrm{mmol} / \mathrm{l})\end{array}$ & $1.82 \pm 0.02$ & $1.84 \pm 0.03$ & 0.234 & $1.83 \pm 0.03$ & $1.85 \pm 0.03$ & 0.004 \\
\hline $\begin{array}{l}\text { ICAM- } 1 \text {, } \\
\text { fasting } \\
(\mathrm{ng} / \mathrm{ml})\end{array}$ & $256 \pm 67$ & $308 \pm 84$ & 0.037 & $296 \pm 80$ & $314 \pm 93$ & 0.346 \\
\hline $\begin{array}{l}\text { ICAM-1, } \\
\text { postprandial } \\
(\mathrm{ng} / \mathrm{ml})\end{array}$ & $248 \pm 69$ & $272 \pm 86$ & 0.322 & $268 \pm 81$ & $272 \pm 93$ & 0.849 \\
\hline
\end{tabular}

The variables were described by arithmetic mean \pm standard deviation or with median and interquartile range.

Table 4 shows concentrations of biochemical parameters, markers of inflammation, oxidative stress and endothelial dysfunction, fasting and postprandial in $\mathrm{HL}$ genotype subgroups.

Again, triglycerides concentration have increased postprandially in both genotype subgroups, but relative triglyceride increase did not differ between $\mathrm{HL}$ subgroups $( \pm \mathrm{SD})(1.0 \pm 0.7 \mathrm{mmol} / 1 \quad(62 \%)$ vs. $0.8 \pm 0.6$ $\mathrm{mmol} / \mathrm{l}(66 \%) ; \mathrm{P}=0.064$, in HL group 1 and HL group $(2+3)$, respectively).

There was no significant, clinically meaningful change for any of the measured parameters, before and after the meal in both HL genotype subgroups.

There was no difference between HL subgroups in levels of all measured parameters (nor between fasting state values, neither postprandially), except for the levels of fasting triglycerides which differed significantly between HL group 1 and group $(2+3)(\mathrm{P}=0.042)$.

Other potential modifying factors of fasting and postprandial state

Mean concentrations of all tested biochemical parameters, markers of inflammation, oxidative stress and endothelial dysfunction did not differ relative to the smoking status, nor in the fasting, neither in the postprandial state $(\mathrm{P}>0.05$ for all differences, data not shown).

We have also tested the differences in fasting and postprandial levels of markers of interest relative to the BMI. Statistically significant differences between normal and overweight (BMI $\geq 25 \mathrm{~kg} / \mathrm{m}^{2}$ ) study subjects were observed for fasting and postprandial triglycerides, hsCRP and fasting ICAM-1, whereas normal and obese $\left(B M I \geq 30 \mathrm{~kg} / \mathrm{m}^{2}\right)$ study subjects differed in fasting and 
postprandial concentrations of hsCRP and postprandial TAS concentration (Table 5).

We have analyzed the potential associations between parameters of interest and our results provide the evidence for the association of hsCRP with BMI ( $\mathrm{r}=0.42$, $\mathrm{P}<0.001)$ and TAS $(\mathrm{r}=0.30, \mathrm{P}<0.001)$ in the fasting state as well as postprandially $(\mathrm{r}=0.39, \mathrm{P}<0.001 ; \mathrm{r}=0.34$, $\mathrm{P}<0.001$, for hsCRP-BMI and hsCRP-TAS, respectively).

Moreover, we have assessed the possible association of family history with the fasting and postprandial concentrations of the parameters of interest. Our results show a marked statistical difference between subjects with and without positive family history of hypertension in postprandial triglycerides (2.1 (1.6-2.9) vs. $2.7(2.1-3.5) \mathrm{mmol} / \mathrm{l}, \mathrm{P}=0.016)$. Furthermore, subjects with a positive family history of acute myocardial infarction had higher fasting (1.3 (1.1-1.9) vs. 1.9 (1.42.9) $\mathrm{mmol} / \mathrm{l}, \mathrm{P}=0.004)$ and postprandial triglyceride (2.2 (1.8-3.1) vs. $2.8 \quad(2.2-4.5) \quad \mathrm{mmol} / \mathrm{l}, \quad \mathrm{P}=0.039) \quad$ and postprandial TAS concentration ( $1.83 \pm 0.03$ vs. $1.85 \pm 0.04$ $\mathrm{mmol} / \mathrm{l}, \mathrm{P}=0.006$ ).

\section{Discussion}

The major finding of our study was the lack of association of markers of inflammation, oxidative stress and endothelial dysfunction with postprandial hypertriglyceridemia. There was a significant increase of triglycerides after $3 \mathrm{~h}$. However, this increase was not accompanied by a significant increase of hsCRP, TAS and ICAM-1 postprandially. Furthermore, we did not observe any difference in response to the standardized high-calorie meal relative to the genetic polymorphisms of APOA5 and HL.

Literature reports on this issue are still inconsistent. Ferreira et al. (2004) have found that a single high-fat meal leads to a significant elevation of plasma endothelial microparticles levels in healthy, normolipidemic subjects and correlates with a postprandial elevation of serum triglycerides. However, their study group was small, 18 healthy subjects.

Ceriello et al. (2004) have observed the increase in nitrotyrosine, ICAM-1, vascular cell adhesion molecule-1 (VCAM-1) and E-selectin plasma levels, in 20 healthy subjects $3 \mathrm{~h}$ after the high-fat meal, and after $4 \mathrm{~h}$ in 30 type 2 diabetic patients.

Patel et al. (2009) have found a significant increase of postprandial triglycerides and significant correlation of plasma triglycerides with ICAM-1 and
VCAM-1, in 8 healthy males. In another study, Peairs et al. (2011) have observed the postprandial increase of CRP, while tumor necrosis factor- $\alpha(\mathrm{TNF}-\alpha)$ decreased and VCAM-1 tended to decrease following the meal in 11 overweight and obese individuals.

There are many possible explanations for the difference between the results observed in the abovementioned studies and our own study. Those studies have included a small number of subjects. There was a large gender and ethnical difference between different study groups. A large heterogeneity in consumed meals, across different studies could have also caused differences in observed relations between the studied biochemical molecules. Furthermore, some investigators have included only young and healthy participants, while others have studied the obese and overweight or diabetic patients. It has been shown previously and we have confirmed in our study that obesity can be potential modifying factor of postprandial triglyceride and inflammatory response. Our overweight and obese study subjects had substantially higher concentrations of those markers than normal subjects in the fasting state and postprandially. Moreover, hsCRP was associated with BMI in the fasting state and postprandially in our study group. CRP is an important mediator of the endothelial dysfunction and oxidative stress (Colak et al. 2012). The observed association of hsCRP and BMI clearly shows that a body weight is a variable strongly linked to the level of inflammation in the circulation.

Family history is of cardiovascular disease is another important discriminating factor for the variations in postprandial triglyceride increase. Interestingly, our study has shown that positive family history of hypertension and acute myocardial infarction are significantly associated with differences in postprandial triglyceride concentration.

In contrast to the above mentioned studies, other authors have failed to observe the association of postprandial triglycerides with markers of inflammation, oxidative stress and endothelial dysfunction. Tsai et al. (2004) have studied 16 healthy young men and they found no significant changes in serum hsCRP, plasma soluble ICAM-1 and VCAM-1 after the high-fat meal.

Rubin et al. (2008) have reported the lack of association between postprandial triglycerides, ICAM-1, VCAM-1 and E-selectin after the standardized lipid-rich meal in 30 young healthy subjects with normal fasting triglycerides. 
Denniss et al. (2008) did not observe any effect of postprandial dyslipidemia on plasma malondialdehyde, CRP, ICAM-1 and VCAM-1 in 27 healthy young subjects.

Liu et al. (2008) have studied the effect of highfat meal after $4 \mathrm{~h}$ on 60 hypertensive patients and 20 healthy participants. They showed a significant increase in plasma triglycerides, but not in TNF- $\alpha$, hsCRP, soluble P-selectin and plasminogen activator inhibitor type 1 (PAI-1) antigen levels in healthy participants. There was a significant increase of the studied markers in hypertensive patients.

In the study published by MacEneaney et al. (2009), postprandial CRP, VCAM-1 and ICAM-1 changed neither in 10 normal weight nor in 8 overweight adolescent boys. Circulating leukocytes and plasma IL-6 levels increased in the normal weight and overweight groups $6 \mathrm{~h}$ postprandially in both experimental conditions.

Several authors have reported that APOA5 $-1131 \mathrm{~T} / \mathrm{C}$ and -250G/A HL polymorphisms were associated with a higher postprandial lipemic response in young healthy males (Moreno-Luna et al. 2007, JiménezGómez et al. 2008).

This association was also proven by other authors, but for Korean and Chinese men and women (Jang et al. 2004, Zhao et al. 2006). We believe that ethnical differences could have caused these inconsistencies of results.

It is well known that smoking status can be very powerful modifying factor for triglyceride levels together with postprandial hyperglycemia and inflammatory markers. We have therefore analyzed the association of smoking status with fasting and postprandial concentration of biochemical markers of inflammation, oxidative stress and endothelial dysfunction. However, in our study population, smoking did not prove to be important modifying factor for postprandial response.

\section{Limitations and Strengths of the Study}

We are fully aware that information regarding the dietary habits of the studied population, could substantially increase the value of the study and possibly even explain, at least partially, the existing differences between our work and other published studies. However, with much regret we can not provide any information about the dietary habits of our population, since this information was not collected at the time of the patient recruitment.

We chose to measure studied parameters at $3 \mathrm{~h}$ after the high-fat meal. Since different investigators have studied different time points, it could be possible that the positive postprandial response occurs either earlier or later than $3 \mathrm{~h}$ after the high-calorie meal.

We are also aware that the exclusion of female subjects from this investigation limits the generalizability of our results.

However, we believe that this study provides the firm evidence for the lack of association between inflammatory and endothelial markers with postprandial hypertriglyceridemia in healthy male adults, $3 \mathrm{~h}$ after the high calorie meal. To the best of our knowledge, this study has included the largest population of subjects, thus minimizing the probability of Type 1 error, when due to the small sample size, the significant difference is found by pure chance only, when actually there is none (Simundic 2013).

\section{Conclusion}

Our data show that postprandial hypertriglyceridemia is not associated with the increase of concentrations of hsCRP, TAS and ICAM-1. Moreover, family history of hypertension and acute myocardial infarction are associated with markedly higher postprandial triglycerides. Finally, APOA5 $-1131 \mathrm{~T} / \mathrm{C}$ and -250G/A HL polymorphisms are not associated with differences in postprandial triglyceride response.

\section{Conflict of Interest}

There is no conflict of interest.

\section{Acknowledgements}

This study was supported by Ministry of Science, Education and Sports, Republic of Croatia project \#1341340227-0200. The authors also wish to thank to MaríaJosé Ariza Corbo of the Laboratorio de Lípidos y Arteriosclerosis (LLA) Centro de Investigaciones Médico-Sanitarias (CIMES) Universidad de Málaga for genotyping a subset of patient samples.
Abbreviations
APOA5, apolipoprotein A5
BMI, body mass index
CAD, coronary artery disease
ELISA, enzymimmunoassay 
HL, hepatic lipase

hsCRP, high-sensitivity C-reactive protein

ICAM-1, intercellular adhesion molecule-1

PAI-1, plasminogen activator inhibitor type 1

PCR, polymerase chain reaction

RFLP, restriction fragment length polymorphism
RT-PCR, real time PCR

TAS, total antioxidant status

TNF- $\alpha$, tumor necrosis factor- $\alpha$

VCAM-1, vascular cell adhesion molecule-1

$\mathrm{w} / \mathrm{h}$, waist to hip ratio

\section{References}

CERIELLO A, QUAGLIARO L, PICONI L, ASSALONI R, DA ROS R, MAIER A, ESPOSITO K, GIUGLIANO D: Effect of postprandial hypertriglyceridemia and hyperglycemia on circulating adhesion molecules and oxidative stress generation and the possible role of simvastatin treatment. Diabetes 53: 701-710, 2004.

CHAPMAN MJ, GINSBERG HN, AMARENCO P, ANDREOTTI F, BORÉN J, CATAPANO AL, DESCAMPS OS, FISHER E, KOVANEN PT, KUIVENHOVEN JA, LESNIK P, MASANA L, NORDESTGAARD BG, RAY KK, REINER Z, TASKINEN MR, TOKGÖZOGLU L, TYBJÆRG-HANSEN A, WATTS GF; EUROPEAN ATHEROSCLEROSIS SOCIETY CONSENSUS PANEL: Triglyceride-rich lipoproteins and high-density lipoprotein cholesterol in patients at high risk of cardiovascular disease: evidence and guidance for management. Eur Heart J 32: 1345-1361, 2011.

COLAK E, MAJKIC-SINGH N, ZORIC L, RADOSAVLJEVIC A, KOSANOVIC-JAKOVIC N: The role of CRP and inflammation in the pathogenesis of age-related macular degeneration. Biochem Med 22: 39-48, 2012.

DENNISS SG, HAFFNER TD, KROETSCH JT, DAVIDSON SR, RUSH JWE, HUGHSON RL: Effect of short-term lycopene supplementation and postprandial dyslipidemia on plasma antioxidants and biomarkers of endothelial health in young, healthy individuals. Vasc Health Risk Manag 4: 213-222, 2008.

FERNÁNDEZ-REAL JM, GARCÍA-FUENTES E, MORENO-NAVARRETE JM, MURRI-PIERRI M, GARRIDOSÁNCHEZ L, RICART W, TINAHONES F: Fat overload induces changes in circulating lactoferrin that are associated with postprandial lipemia and oxidative stress in severely obese subjects. Obesity 18: 482-488, 2010.

FERREIRA AC, PETER AA, MENDEZ AJ, JIMENEZ JJ, MAURO LM, CHIRINOS JA, GHANY R, VIRANI S, GARCIA S, HORSTMAN LL, PUROW J, JY W, AHN YS, DE MARCHENA E: Postprandial hypertriglyceridemia increases circulating levels of endothelial cell microparticles. Circulation 110: 35993603, 2004.

JANG Y, KIM JY, KIM OY, LEE JE, CHO H, ORDOVAS JM, LEE JH: The $-1131 \mathrm{~T} \rightarrow$ C polymorphism in the apolipoprotein A5 gene is associated with postprandial hypertriacylglycerolemia; elevated small, dense LDL concentrations; and oxidative stress in nonobese Korean men. Am J Clin Nutr 80: 832-840, 2004.

JIMÉNEZ-GÓMEZ Y, PÉREZ-JIMÉNEZ F, MARÍN C, GÓMEZ P, MORENO R, DELGADO J, PÉREZMARTÍNEZ P, GÓMEZ MJ, LÓPEZ-MIRANDA J: The -250G/A polymorphism in the hepatic lipase gene promoter influences the postprandial lipemic response in healthy men. Nutr Metab Cardiovasc Dis 18: 173181, 2008.

KARPE F: Postprandial lipoprotein metabolism and atherosclerosis. J Intern Med 246: 341-355, 1999.

LIU L, ZHAO SP, WEN T, ZHOU HN, HU M, LI JX: Postprandial hypertriglyceridemia associated with inflammatory response and procoagulant state after a high-fat meal in hypertensive patients. Coron Artery Dis 19: 145-151, 2008.

MAASZ A, KISFALI P, JAROMI L, HORVATOVICH K, SZOLNOKI Z, CSONGEI V, SAFRANY E, SIPEKY C, HADARITS F, MELEGH B: Apolipoprotein A5 gene IVS3+G476A allelic variant confers susceptibility for development of ischemic stroke. Circ J 72: 1065-1070, 2008.

MACENEANEY OJ, HARRISON M, O'GORMAN DJ, PANKRATIEVA EV, O'CONNOR PL, MOYNA NM: Effect of prior exercise on postprandial lipemia and markers of inflammation and endothelial activation in normal weight and overweight adolescent boys. Eur J Appl Physiol 106: 721-729, 2009. 
MORENO-LUNA R, PEREZ-JIMENEZ F, MARIN C, PEREZ-MARTINEZ P, GOMEZ P, JIMENEZ-GOMEZ Y, DELGADO-LISTA J, MORENO JA, TANAKA T, ORDOVAS JM, LOPEZ-MIRANDA J: Two independent apolipoprotein A5 haplotypes modulate postprandial lipoprotein metabolism in a healthy Caucasian population. J Clin Endocrinol Metab 92: 2280-2285, 2007.

NAPPO F, ESPOSITO K, CIOFFI M, GIUGLIANO G, MOLINARI AM, PAOLISSO G, MARFELLA R, GIUGLIANO D: Postprandial endothelial activation in healthy subjects and in type 2 diabetic patients: role of fat and carbohydrate meals. J Am Coll Cardiol 39: 1145-1150, 2002.

PATEL S, PURANIK R, NAKHLA S, LUNDMAN P, STOCKER R, WANG XS, LAMBERT G, RYE KA, BARTER PJ, NICHOLLS SJ, CELERMAJER DS: Acute hypertriglyceridaemia in humans increases the triglyceride content and decreases the anti-inflammatory capacity of high density lipoproteins. Atherosclerosis 204: 424$428,2009$.

PEAIRS AD, RANKIN JW, LEE YW: Effects of acute ingestion of different fats on oxidative stress and inflammation in overweight and obese adults. Nutr J 10: 122, 2011. doi: 10.1186/1475-2891-10-122

PENNACCHIO LA, RUBIN EM: Apolipoprotein A5, a newly identified gene that affects plasma triglyceride levels in humans and mice. Arterioscler Thromb Vasc Biol 23: 529-534, 2003.

RUBIN D, CLAAS S, PFEUFFER M, NOTHNAGEL M, FOELSCH UR, SCHREZENMEIR J: s-ICAM-1 and sVCAM-1 in healthy men are strongly associated with traits of the metabolic syndrome, becoming evident in the postprandial response to a lipid-rich meal. Lipids Health Dis 7: 1-7, 2008.

SANTAMARINA-FOJO S, GÓNZALEZ-NAVARRO H, FREEMAN L, WAGNER E, NONG Z: Hepatic lipase, lipoprotein metabolism, and atherogenesis. Arterioscler Thromb Vasc Biol 24: 1750-1754, 2004.

SIMUNDIC AM: Practical recommendations for statistical analysis and data presentation in Biochemia Medica journal. Biochem Med 22: 15-23, 2012.

SIMUNDIC AM: Bias in research. Biochem Med 23: 12-15, 2013.

TSAI WC, LI YH, LIN CC, CHAO TH, CHEN JH: Effects of oxidative stress on endothelial function after a high-fat meal. Clin Sci 106: 315-319, 2004.

VALDIVIELSO P, ARIZA MJ, DE LA VEGA-ROMÁN C, GONZÁLEZ-ALEGRE T, RIOJA J, ULZURRUN E, GONZÁLEZ-SANTOS P: Association of the -250G/A promoter polymorphism of the hepatic lipase gene with the risk of peripheral arterial disease in type 2 diabetic patients. J Diabetes Complications 22: 273-277, 2008.

WHO Expert Consultation: Waist Circumference and Waist-Hip Ratio. Geneva, 8-11 December 2008.

ZHAO S, XIE X, NIE S: The $-250 \mathrm{G} \rightarrow$ A polymorphism in the human hepatic lipase gene promoter affects blood lipids in Chinese. Clin Chim Acta 365: 149-152, 2006. 